\title{
'It is a classic Keynesian depression, I would not refrain from the term'
}

\author{
Interview with Fernando Cardim de Carvalho
}

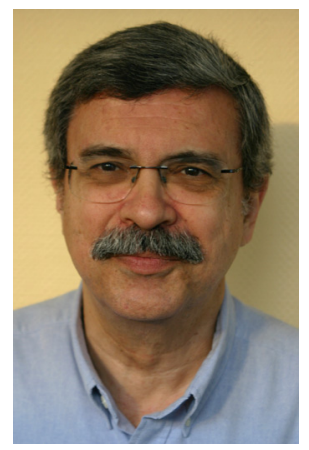

\begin{abstract}
Fernando Cardim de Carvalho is Professor emeritus for economics at the Federal University of Rio de Janeiro. His research interests include monetary economics and economic policies. He was a consultant for the National Social and Development Bank of Brazil and for the Economic Commission for Latin America and the Caribbean of the United Nations. Fernando Cardim de Carvalho is a co-founder of the Brazilian Keynesian Association and author of more than 160 publications.
\end{abstract}

What was your motivation to become an economist and how did you get in contact with Keynesian and post-Keynesian economics?

My story is not very different from that of others of my generation who faced a military dictatorship in Brazil. In the late 1960s and early 1970s, we began mostly as student activists and we were, even before making any choice of career, all Marxists. We all began the adult phase of our lives with a certain previous inheritance which more or less shaped the evolution of our generation when we began to take over the academic community.

My choice of economics in itself was nearly accidental. My wife was doing political science and so we thought one of us had to study in a field providing financial security. So I went into economics for no particular reason. My undergraduate studies were done in a very mainstream department, very neoclassical, which frankly I think was good because it is important to know with whom you are debating. Then, in the 1970s, there was one university, the University of Campinas, that opened a graduate master programme on Marx, still during the military regime, which was really unusual and unexpected. This was also the time in which the first news came that the world was not only neoclassical or Marxist. The first book I ever read in this tradition was Leijonhufvud's On Keynesian Economics and the Economics of Keynes, even though later I realized he was not considered to be a post-Keynesian and actually did not consider himself to be a post-Keynesian. This book was my first contact. I was trained in the IS-LM tradition and standard textbooks, and so Leijonhufvud was exciting to read. Right after that I heard of Paul Davidson's Money and the Real World that came out in 1972. So if you knew Leijonhufvud, you would know about Clower, and if you heard of Clower you would hear about Davidson and Minsky.

At this time we were beginning to feel a little bit uncomfortable with traditional Marxian economics. Keynes was still considered bourgeois economics but seemed more interesting. For me the crucial difference was that in $1981 \mathrm{I}$ was a student in the first summer school that took place in Trieste, organized by Jan Kregel, Pierangelo Garegnani and Sergio Parrinello. It was something that probably can never be repeated, because a team of people like that is very hard to put together. The dialogue between them was very complicated, some sessions would end up in fights, in real 
fights, not in the sense where I merely disagree with you, but that each presenter really believed that his or her opponent was completely wrong. That was the atmosphere, but for a student it was fascinating. You had Minsky, Davidson, Kregel, Garegnani, Ed Nell, Bertram Schefold, Don Harris, Sidney Weintraub and Geoff Harcourt, among others, and they all debated very heatedly.

So in 1982 I went to Rutgers, because in 1981 a post-Keynesian institute had just been created, with Paul Davidson, Jan Kregel, Nina Shapiro and Alfred Eichner, who was very important in the late 1970s, early 1980s. Between the summer school and the following year, however, there was a huge fight in the economics department at Rutgers and the idea of the institute had been abandoned. Kregel left Rutgers, and only Nina Shapiro, Al Eichner and Paul Davidson, who first resigned but later came back to the graduate school, stayed in the department. There were also some Marxian economists, like Robert Guttman, Lourdes Beneria and Michelle Naples, but the first two also left soon afterwards. Finally, James Street, a leading institutionalist development economist, was there. All in all, even without a post-Keynesian institute, it was not a bad time to be in Rutgers.

What is the situation of post-Keynesian economics in Brazil today? Why is it so much better than in most other countries?

To some extent it is a mystery. Argentina for example has a similar history but for some reason is not in the same situation. In any case, the most important factor perhaps is that we already had a strong non-Marxian, non-orthodox tradition, which was the structuralist development theory, people who were very close to Keynes. Raul Prebisch practically was the first person to present Keynes to Latin America, and we had also Celso Furtado who wrote a seminal and brilliant book on the economic history of Brazil in the Keynesian tradition. In Brazil we kept this tradition alive perhaps more than in other countries in Latin America. In part it was for political reasons, because the military regimes in Argentina, Chile and Uruguay were much tougher than the ones we had in Brazil and had a much more destructive impact on the universities. In Brazil, the military regime did not really prevent you from studying. When I went to Rutgers, I got a grant from the Brazilian government still in times of the military regime. The second reason was the economy itself, because if you talk about equilibrium in an economy like Brazil, you do not attract too many people outside the community of economists and even within. So you have a context in which people were looking for new answers. We always had students, we could always train new generations, that is why the post-Keynesian community is so strong in Brazil. We also created the Brazilian Keynesian Association five years ago and had five annual meetings. We are recognized in the political debate. We get called all the time by the journalists specialized in economic problems and by the government. People are convinced that we have something to say and they are willing to listen.

Let us move on to theory, rather than the institutions. In your book of 1992 on Mr Keynes and the Post Keynesians: Principles of Macroeconomics for a Monetary Production Economy, you emphasize very much the notion of a monetary production economy which is said to be the key feature of post-Keynesian economics. Has there been some formalization of this notion of a monetized production economy?

The purpose of the book was to provide a general framework. What we do now is to relate specific topics to the general structure, but most of the projects we develop are at a more concrete level. A framework is a starting point. Then you have to move on and to end up with empirical work. I think the theoretical debate among post-Keynesians is 
fundamental but we can only face neoclassical economists in debate and earn support to advance alternative policies if we show the public - students, economists and the general public - that we can explain the real world better than they do.

In the same book, you were rather critical of the distinction between workers and capitalists. Should more effort be put into studies of personal income distribution rather than in those on functional income distribution?

I was critical of the way the distinction between workers and capitalists came out in Kalecki and Kaldor. Maybe because of my Marxian inheritance, I assume workers and capitalists have to do with the production process. Both Kaldor and Kalecki defined the groups in terms of consumption propensities instead. My view was that they were differentiating poor people, who are consuming everything they get, from rich people, who save because they are not able to consume. But if you have a middle class, how do you handle people who are in it? A lot of workers actually save, they have the capacity and they have plans for their savings. The use of the language 'workers versus capitalists' in those models is misleading.

In a paper from 1990 on Keynes and the Long Period, you were complaining that post-Keynesians were not providing enough links between the short period and the long period. Do you consider stock-flow consistent models that researchers are working on, in particular in Brazil with Claudio Dos Santos, as a way to integrate the short run with the long run?

It is one way, not the way. But how to combine stock analysis with flow analysis has always been a problem. In the Trieste summer school this was the central thing, because the idea was that you could have a Sraffian long run and a Keynesian short run. Personally I do not believe it can work because there is an implicit short run in the Sraffian theory and there is an implicit long run in Keynesian theory. When you put both together, then you can barely agree on anything. What I was trying to say in the paper was precisely this: there is a long run in Keynesian economics that is related to the kind of dynamics that is implicit in the short run. But the point of the Keynesian approach, in my view, is that it has a theory of how agents react to errors and they do not react in the way which is implicit in the Sraffian model of gravitation. From the Keynesian point of view, the process is not consistent, because you will never move, you will never be attracted towards that gravitation point. Just to give an example: the idea that economic activity moves from the sectors where profit rates are low to the sectors were profit rates are high implies that you can transport your capital from one sector to the other. In a Keynesian analysis, however, if you are underperforming, you will not be able to realize your capital in a value that is enough to avoid bankruptcy. So the problem I had with this communion of the Sraffian and the Keynesian models - and of course many people had the same problem at the time - was that the Keynesian long-period equilibrium was not an attractor, and thus you had to think of a different way about how the economy works. In other words, both theories were not complementary, they were competing theories.

What do you think post-Keynesians can contribute to current discussions on economic policy? What is your view on the financial market crisis?

It is particularly the kind of studies that developed around Minsky's theory of financial fragility that are the most promising path to understand what is happening and eventually to think in terms of policies. Basel III incorporates two of Minsky's central 
concerns. According to Minsky, you are in a fragile situation when you borrow and when you mismatch your liabilities and assets, so it exposes you to a solvency risk and a liquidity risk. Basel III first posed a limit to the leverage ratio and second it has put constraints on the degree of illiquidity that is acceptable. The limits are still low and difficult to work out in practical terms but it is a turn in the right direction after years of neglect.

In the financial system, the Keynes-Minsky model is working very well, and the alternatives are not really competitive. You see lots of books that are using some of Keynes's and Minsky's arguments without any attribution to them. Perhaps their authors do not even know these two economists, like Paul Krugman who wrote that he has just discovered Minsky; but even Keynes himself seems to be a recently found reference for him.

A related but tougher question for post-Keynesians is expansionary policies. In Brazil, expansionary policies are not working as expected. Expansion is much weaker than it should be.

The question is, when does the multiplier work? This area should be an obvious one for Keynesians, but here we are weak. Post-Keynesians are a small group, you have few people, even if you add everybody. So it is not easy to cover everything that is relevant and for a long time money and finance were much more sexy and everybody wanted to say something on these topics, as well as on uncertainty and the monetary production economy, but not on consumption and the multiplier.

I spend a lot of my time in Portugal. Now they are finding out that austerity is not working. If you raise taxes and cut spending - what else should you expect?! They had a deficit target and every month they act surprised because tax revenues fall below the target. Why are we not on top of this debate? Why can we not just come up with numbers? I am really concerned, because the windows of opportunity for critics of orthodox economics will not remain open forever. I have no idea of what is going to happen in Europe. The signs of political disintegration are particularly worrying. We are slow in making the argument and showing the numbers. I think it is worrying because this is a classic Keynesian depression, I would not refrain from the term, I think it is a depression. It is a big shock with long-term stagnating consequences.

The interview was conducted by Marc Lavoie and Torsten Niechoj in October 2012.

\section{SELECTED PUBLICATIONS OF FERNANDO CARDIM DE CARVALHO}

Cardim de Carvalho, F. (1990): Keynes and the long period, in: Cambridge Journal of Economics, 11(1), 66-81.

Cardim de Carvalho, F. (1992): Mr Keynes and the Post Keynesians: Principles of Macroeconomics for a Monetary Production Economy, Aldershot: Edward Elgar.

Cardim de Carvalho, F. (2003): Decision-making under uncertainty as drama: Keynesian and Shacklean themes in three of Shakespeare's tragedies, in: Journal of Post Keynesian Economics, 25(2), 189-218.

Cardim de Carvalho, F. (2010): Uncertainty and money: Keynes, Tobin and Kahn and the disappearance of the precautionary demand for money from liquidity preference theory, in: Cambridge Journal of Economics, 34(4), 709-725.

Cardim de Carvalho, F. (2011): Financial stability regulation in Brazil (1998-2008), in: Revista de Economia Política, 31, 858-862.

Cardim de Carvalho, F. (2012): Aggregate savings, finance and investment, in: Intervention: European Journal of Economics and Economic Policies, 9(2), 197-214. 